\title{
Occurrence of cancer in women in the meat industry
}

\author{
E S JOHNSON, H R FISCHMAN, G M MATANOSKI, E DIAMOND
}

From the Department of Epidemiology, The Johns Hopkins University School of Hygiene and Public Health, Baltimore, MD 21205, USA

ABSTRACT A follow up study of 7261 white women from a meatcutters' union was conducted between July 1949 and December 1980. Proportional mortality ratio (PMR) and standardised mortality ratio (SMR) analyses, using the United States general population mortality rates, were conducted for the group as a whole and for subgroups defined according to the four main job categories in the meat industry, and a fifth category of workers from outside the industry but belonging to the same union (control group). At least a threefold risk of death was observed both for myeloid leukaemia and non-Hodgkin's lymphomas among workers in the meat department of retail food stores. No excess risk from these diseases was observed in the control group. SMRs of $4.56,4.02$, and 1.95 , which were statistically significant, were observed for lung cancer among workers in chicken slaughtering plants, meatpacking plants, and retail food stores respectively. The lung cancer SMR for abattoir workers was 1.41 (not significant) and 1.11 for workers in non-meat companies. The role of potentially harmful exposures within the industry in the occurrence of these excesses is discussed.

No studies have been published on the mortality experience of women who work in the meat industry. The wrapping and labelling of meat have traditionally been performed predominantly by women; a typical example may be found in the meat department of supermarkets. In the industry heat is used to cut and seal plastic during the wrapping process and to stick labels on the wrap. Anyone performing such tasks could, until recently, be heavily exposed to fumes emitted from the thermal decomposition of the plastic and develop the acute syndrome generally referred to as "meatwrappers asthma."1-5 To date, however, no information is currently available on the possible long term effects of such an exposure. Various plastics have been used to wrap meat, including polystyrene, polyvinylidene polyethylene, rubber hydrochloride, cellophane, and polyvinyl chloride (PVC). Data on the effects of these substances or their thermal decomposition products in man or animals are sparse. Pure implants of polyethylene, polystyrene, and PVC have been shown to be carcinogenic in rats and mice. ${ }^{6}$ Some of the thermal decomposition products that workers are exposed to when PVC is heated include benzene, phthalic anhydride, and phthalates. ${ }^{7-10}$ Benzene is leukaemogenic in man, and the other two have been shown to cause tumours in animals. ${ }^{11} 12$

Female workers in the industry are also potentially

Accepted 21 January 1986 exposed to viruses which naturally cause leukaemia and lymphosarcoma in cattle and chickens-namely, the bovine leukaemia virus (BLV), the avian leukosis viruses, and Marek's disease virus. ${ }^{13-15}$ These viruses are commonly present in diseased and healthy animals destined for human consumption. ${ }^{15-20}$ Other potentially harmful exposures within the industry include exposure to nitrosamines during the curing of meat, ${ }^{21} 22$ butylated hydroxyanisole (BHA), and butylated hydroxytoluene (BHT) which are antioxidants used as preservatives, and smoke during the smoking of meat. Nitrosamines are powerful carcinogens, ${ }^{23}$ and BHA and BHT are associated with tumour induction in animals. ${ }^{2425}$ In view of the occurrence of these types of exposure in the industry, it was decided to conduct a mortality study of workers to examine their long term effects, if any.

\section{Materials and methods}

The study population was derived from a total of 28901 individuals who were members of a local meatcutters' union in Baltimore, Maryland, between July 1949 and December 1979. All the four main job categories within the meat industry were represented in the membership. Thus the group included workers from abattoirs, meatpacking plants (no slaughtering done), meat department of grocery stores/supermarkets, and chicken slaughtering plants. Also 
included was a fifth category of workers from companies outside the meat industry employed for example in soft drinks manufacturing, who were also members of the union (control group). Over $95 \%$ of the membership lived in Maryland and the rest were from neighbouring states; $60 \%$ of the membership were from the city of Baltimore itself.

The relevant demographic and other identifying information was available from union records, which also contained an accurate employment history (based on monthly payment of union dues). Union records did not contain information on race, and information on date of birth was missing for 1881 individuals, $6.5 \%$ of the membership. Since race was associated with job category $(94 \%$ of all those who had died who worked in supermarkets were white, whereas $67 \%$ who worked in chicken slaughtering plants were non-whites), this had to be taken into account. Accordingly, since all deceased individuals with death certificates had accurate information on race, all others were assigned a race based on the racial distribution for a given sex in a particular job category among deceased individuals with death certificates. A questionnaire survey of companies involving more than half the current membership indicated that the racial distribution by job category of current workers was almost identical with that of deceased union members. Similarly, in order not to overestimate mortality by excluding the few individuals without date of birth who were all known to be alive or lost to follow up, these individuals were each assigned a date of birth, some estimated from a modified method by Block et al, ${ }^{26}$ and others from a distribution of median age by year of first joining the union derived from all members with known year of birth. The modified method of Block et al tested on 1000 subjects in the study yielded a correlation between known year of birth and estimate year of birth of $r^{2}=0.9$ with a standard error of 3.4 for men and $r^{2}=0.8$ with a standard error of 4.4 for women.

The 28901 individuals were followed up until the end of December 1980. At the end of the study, 23364 $(80.8 \%)$ were alive, $3350(11.6 \%)$ were dead, and $2187(7.6 \%)$ were lost to follow up. Death certificates were not available for 200 individuals, of whom $78.5 \%$ were men as compared with $77.7 \%$ men recorded for all deaths. A total of 7261 white women was identified as described above; they constitute the study population and we report their mortality experience.

A total of 535 deaths occurred among the 7261 individuals during the study period. Cause of death was not available for 29 deaths and they were thus assumed to have died of unknown causes. Of the 7261 women, $6923(95 \cdot 3 \%)$ had worked in only one of the five job categories throughout their entire mem- bership in the union (life time job) and were thus $\overline{\bar{z}}$ divided into their respective categories and analysed $\frac{\varrho}{z}$ separately. The findings of this study are based on proportional mortality ratio (PMR) and standardised? mortality ratio (SMR) estimations, using these sub- $\overrightarrow{\vec{*}}$ divisions. For the SMR analysis, those lost to followup were assumed to be alive at the end of the study.들 Two other sets of results are presented in the tables $\overline{\overline{0}}$. but for the most part will not be commented on as $\overrightarrow{\widetilde{\alpha}}$ they do not materially change the findings; these are $\varrho$ (1) SMR estimations also by life time job but with क those lost to follow up withdrawn at the time of loss $\vec{\circ}$ and (2) SMR estimations with the study group divided according to job category ever worked in, $\vec{\omega}$ with those lost to follow up assumed alive at the end $\frac{}{\circ}$ of the study: this analysis was included because it used $\frac{\Phi}{3}$ all 7261 individuals. Similarly, the PMR estimations were included because information on race and date $\omega$ of birth was complete for this analysis and would thus ${ }_{i}$ serve as a useful comparison for the SMR analysis for 6 which race, and in a minority of cases date of birth,o were artificially assigned. The rates used to calculate? the expected number of deaths were derived from the $c s$ United States general population.

\section{Results}

Causes of death from cancer of all organs and systems $\vec{\bullet}$ were investigated; however, for brevity, only the fog lowing results are presented in the tables: (1) resuris for all tumours of the haemopoietic/lymphatic s/s-0 tems, whether statistically significant or not, because these are the tumour types associated with oncogenico viruses in cattle and chickens and (2) results for other응 cancers, only if any of the estimates of risk was statis- $\_$ tically significant. In both cases in order to control for $\overrightarrow{0}$ geographical variation in using United States rates 3 for comparison, a subset of the population in a given job category consisting of Baltimore residents only? was selected and SMRs for these cancers calculatedo using Baltimore general population rates in one case 3 and United States rates in another for comparison. This subanalysis was limited to the period 1970 to 1980, for which Baltimore rates were available. The cause specific SMRs may be compared across job cat- egories, as it was found that the age distribution of theo different job categories was virtually identical.

\section{ALL WHITE WOMEN IN THE UNION}

No increased risk of death from tumours of the $N$ haemopoietic/lymphatic systems was observed in the $N$ group as a whole (table 1). Nevertheless, lung cancerN్ was significantly increased by all estimates. Death ${ }_{\sigma}$ from breast cancer was significantly lower than expected. These results will be examined in greater detail under each specific job category. 
Table 1 Cause specific proportional mortality ratios $(P M R)$ and standardised mortality ratios $(S M R)$ for all white women in the union $(n=7261)$ : Meatcutters Union, Baltimore, Maryland (1949-80)

\begin{tabular}{llllll}
\hline Type of cancer & $\begin{array}{l}\text { ICD 8th } \\
\text { revision }\end{array}$ & $\begin{array}{l}\text { Observed } \\
\text { No of deaths }\end{array}$ & PMR & $\begin{array}{l}\text { Lost are alive } \\
\text { SMR }\end{array}$ & $\begin{array}{l}\text { Lost are withdrawn } \\
\text { SMR }\end{array}$ \\
\hline Lymphosarcoma and reticulosarcoma & 200 & 2 & 0.64 & 0.58 & 0.66 \\
Hodgkin's disease & 201 & 1 & 0.58 & 0.48 & 0.53 \\
Leukaemia and aleukaemia & $204-207$ & 5 & 0.95 & 0.85 & 0.95 \\
Cancer of other lymphatic tissue & $202-203,208$ & 3 & 0.90 & 0.87 & 0.98 \\
All haemopoietic/lymphatic cancers & $200-209$ & 12 & 0.88 & 0.80 & 0.89 \\
Lung & $162-163$ & 38 & $2 \cdot 10^{* *}$ & $1.98^{* *}$ & $2.24^{* *}$ \\
Breast & 174 & 27 & $0.65^{*}$ & $0.61^{* *}$ & 0.68 \\
All cancers & $140-209$ & 178 & 1.09 & 1.01 & 1.14 \\
All causes of death & & 535 & & 0.97 & $1.10^{*}$ \\
\hline
\end{tabular}

${ }^{*}$ p-value $<0.05 ;{ }^{* *}$-value $<0.005$.

\section{ABATTOIRS}

There was no increased risk of death for any tumour of the haemopoietic/lymphatic systems, except the SMR of 1.54 for lymphosarcoma and reticulosarcoma based on one death only (table 2). None of the SMRs for the non-haemopoietic/lymphatic cancers was significantly raised.

\section{MEATPACKING PLANTS}

No death from tumours of the haemopoietic/ lymphatic systems was observed in this group of female workers, even though 2.36 were expected. A highly statistically significant raised risk of death from lung cancer was observed by all four estimates of risk (table 3).
Lung cancer (ICD 162-163)

The SMR for lung cancer for women in meatpacking plants was $4.02(p<0.005)$. Eight of the total of 12 deaths recorded $(67 \%)$ occurred between the ages of 35 and 49 and the SMRs for lung cancer in this age group varied between 8.2 and 11.8 . The increased risk did not seem to be associated with entry into the union during a particular period, nor was there any obvious relation between the risk of lung cancer and duration of union membership. It is noteworthy, however, that eight of the 12 deaths occurred in those who had been members of the union for less than five years; the SMR for this group was 5.5. In about $25 \%$ of the study population the date of hire did not coincide with the date of joining the union, hence some

Table 2 Cause specific PMRs and SMRs for white women in abattoirs ( $n=826$ ): Meatcutters Union, Baltimore, Maryland (1949-80). (Figures in parentheses represent SMRs obtained for persons who had ever worked in abattoirs)

\begin{tabular}{|c|c|c|c|c|c|}
\hline Type of cancer & $\begin{array}{l}\text { ICD 8th } \\
\text { revision }\end{array}$ & $\begin{array}{l}\text { Observed } \\
\text { No of deaths }\end{array}$ & $P M R$ & $\begin{array}{l}\text { Lost are alive } \\
\text { SMR }\end{array}$ & $\begin{array}{l}\text { Lost are withdrawn } \\
\text { SMR }\end{array}$ \\
\hline $\begin{array}{l}\text { Lymphosarcoma and reticulosarcoma } \\
\text { Hodgkin's disease } \\
\text { Leukaemia and aleukaemia } \\
\text { Cancer of other lymphatic tissue } \\
\text { All haemopoietic/lymphatic cancers } \\
\text { All cancers } \\
\text { All causes of death }\end{array}$ & $\begin{array}{l}200 \\
201 \\
204-207 \\
202-203,208 \\
200-209 \\
140-209\end{array}$ & $\begin{array}{r}1 \\
0 \\
1 \\
0 \\
2 \\
29 \\
87\end{array}$ & $\begin{array}{l}1.90 \\
1 \cdot 17 \\
0.89 \\
1.05\end{array}$ & $\begin{array}{l}1.54(1.25) \\
0.95(0.76) \\
0.73(0.59) \\
0.87(0.88) \\
0.83(0.80)\end{array}$ & $\begin{array}{l}1.76 \\
1.06 \\
0.82 \\
1.00 \\
0.94\end{array}$ \\
\hline
\end{tabular}

Table 3 Cause specific PMRs and SMRs for white women in meatpacking plants $(n=896)$ : Meatcutters Union, Baltimore, Maryland (1949-80). (Figures in parentheses represent SMRs obtained for persons who had ever worked in meatpacking plants)

\begin{tabular}{|c|c|c|c|c|c|}
\hline Type of cancer & $\begin{array}{l}\text { ICD 8th } \\
\text { revision }\end{array}$ & $\begin{array}{l}\text { Observed } \\
\text { No of deaths }\end{array}$ & $P M R$ & $\begin{array}{l}\text { Lost are alive } \\
\text { SMR }\end{array}$ & $\begin{array}{l}\text { Lost are withdrawn } \\
\text { SMR }\end{array}$ \\
\hline $\begin{array}{l}\text { All haemopoietic/lymphatic cancers } \\
\text { Lung } \\
\text { All cancers } \\
\text { All causes of death }\end{array}$ & $\begin{array}{l}200-209 \\
162-163 \\
140-209\end{array}$ & $\begin{array}{r}0 \\
12 \\
36 \\
101\end{array}$ & $\begin{array}{l}3 \cdot 30^{* *} \\
1 \cdot 14\end{array}$ & $\begin{array}{l}4 \cdot 02 *(3 \cdot 08) \\
1 \cdot 30(1 \cdot 17) \\
1 \cdot 17(1 \cdot 07)\end{array}$ & $\begin{array}{l}4 \cdot 48^{* *} \\
1 \cdot 45^{*} \\
1 \cdot 33^{*}\end{array}$ \\
\hline
\end{tabular}

${ }^{*}$ p-value $<0.05 ;{ }^{* *}$-value $<0.005$. 
Table 4 Cause specific PMRs and SMRs for white women in grocery stores/supermarkets ( $n=3622):$ Meatcutters Union, Baltimore, Maryland (1949-80). (Figures in parentheses represent SMRs obtained for persons who had ever worked in meat department of grocery stores/supermarkets)

\begin{tabular}{|c|c|c|c|c|c|}
\hline Type of cancer & $\begin{array}{l}\text { ICD 8th } \\
\text { revision }\end{array}$ & $\begin{array}{l}\text { Observed } \\
\text { No of deaths }\end{array}$ & $P M R$ & $\begin{array}{l}\text { Lost are alive } \\
\text { SMR }\end{array}$ & $\begin{array}{l}\text { Lost are withdrawn } \\
\text { SMR }\end{array}$ \\
\hline $\begin{array}{l}\text { Lymphosarcoma and reticulosarcoma } \\
\text { Hodgkin's disease } \\
\text { Leukaemia and aleukaemia } \\
\text { Cancer of other lymphatic tissue } \\
\text { All haemopoietic/lymphatic cancers } \\
\text { Lung } \\
\text { Breast } \\
\text { All cancers } \\
\text { All causes of death }\end{array}$ & $\begin{array}{l}200 \\
201 \\
204-207 \\
202-203,208 \\
200-209 \\
162-163 \\
174 \\
140-209\end{array}$ & $\begin{array}{r}1 \\
1 \\
4 \\
3 \\
10 \\
14 \\
8 \\
67 \\
171\end{array}$ & $\begin{array}{l}0.96 \\
1 \cdot 62 \\
2 \cdot 23 \\
2 \cdot 72 \\
2 \cdot 17^{*} \\
2 \cdot 18^{* *} \\
0 \cdot 56 \\
1 \cdot 22^{*}\end{array}$ & $\begin{array}{l}0.82(0.78) \\
1.23(1.16) \\
1.85(1.76) \\
2.46(2.34) \\
1.82(1.72) \\
1.95^{*}(1.85) \\
0.49 *(0.46) \\
1.07(1.04) \\
0.91(0.89)\end{array}$ & $\begin{array}{l}0.87 \\
1.30 \\
1.97 \\
2.63 \\
1.93 \\
2.09 * \\
0.52 \\
1 \cdot 14 \\
0.97\end{array}$ \\
\hline
\end{tabular}

${ }^{*}$ p-value $<0.05 ;{ }^{* *}$ p-value $<0.005$.

caution should be exercised in using the duration of union membership as a surrogate for the duration of employment.

When only workers in meatpacking plants who resided in Baltimore were considered, the SMR for lung cancer for 1970-80 was 4.95 ( $p<0.005)$ using United States rates and $2.92(p<0.005)$ using Baltimore rates. Evidently, therefore, there is at least a threefold excess risk of lung cancer in this group of women.

\section{GROCER Y STORES/SUPERMARKETS}

A statistically significant PMR of $2.17(\mathrm{p}<0.025)$ was observed for all cancers of the haemopoietic/ lymphatic systems in this group (based on 10 deaths), and the corresponding SMR of 1.82 almost reached statistical significance $(0 \cdot 10>\mathrm{p}>0.05)$. The cancers contributing to this excess were leukaemia and aleukaemia and cancer of other lymphatic tissue. Of the non-haemopoietic/lymphatic cancers, only the SMR for lung cancer was significantly raised, whereas the SMR for breast cancer was significantly depressed (table 4).

\section{Leukaemia and aleukaemia (ICD 204-207)}

The PMR for leukaemia and aleukaemia was 2.23 $(0.10>p>0.05)$ and the SMR was 1.85 (not significant), based on a total of four deaths. Three of these were due to myeloid leukaemia; the fourth death was from unspecified leukaemia.

When only residents of Baltimore in this group were considered, the SMR for the period 1970-80 for leukaemia and aleukaemia was 1.56 using United States rates and 1.67 using Baltimore rates (based on one death only). This indicates, however, that use of United States rates did not artificially contribute to the twofold risk of leukaemia observed for the entire group which, in fact, may even be slightly higher.

The fact that at least three deaths from myeloid leukaemia were observed, when a total of $2 \cdot 16$ deaths from all forms of leukaemia were expected, clearly $\frac{\vec{\omega}}{\omega}$ indicates an excess of this type of tumour in the 6 group. In the United States myeloid leukaemia usu- of ally constitutes $36-44 \%$ of all deaths from leukaemia $\checkmark$ and aleukaemia. Thus the observed excess risk of $\stackrel{\circ}{\longrightarrow}$ myeloid leukaemia is roughly 3.5 times that expected. $\vec{P}$ The probability of observing three or more deaths $\mathbb{D}$ when between 0.77 and 0.95 were expected is about 0.05 (Poisson distribution).

Cancer of other lymphatic tissue (ICD 202-203, 208) The PMR for this group of tumours was $2.72(0.108$ $\mathrm{p}>0.05$ ) and the SMR was 2.46 (not significan Although only a total of 1.22 deaths was expect from this group of cancer, three were observed, due to ICD 202, 8th revision (other neoplasms of lymphoid tissue); thus this may indicate an excess risk from ICD 202. This apparent excess of ICD 202 does $\frac{}{\Phi}$ not seem to have resulted artificially because of pref- $\overrightarrow{\vec{O}}$ erential classification of lymphomas under ICD 202 을 rather than ICD 200 (lymphosarcoma and reticulosarcoma); a total of 2.44 deaths from ICDs 200 , 202, 203, and 208 combined was expected, yet four deaths, all from non-Hodgkin's lymphoma (three $\mathbb{\mathbb { D }}$ from ICD 202 and one from ICD 200), were observed. Unfortunately, separate determination of 3 risk for lymphomas was not possible, but it is clear from the above that the occurrence of non-Hodgkin's lymphomas in this group of workers is excessive, and

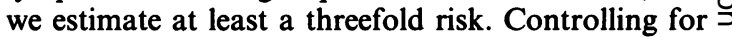
geographical variation did not materially change the $\frac{T}{0}$ results.

Cancer of the lung (ICD 162-163)

A twofold excess risk of lung cancer which was statistically significant was obtained by all four estimates $\omega$ of risk. Five of the total of 14 deaths $(36 \%)$ occurred under the age of 50 . No obvious cohort effect or dose- -0 response like effect was observed, although 10 of the 14 deaths from lung cancer occurred in those who had ? 
Table 5 Cause specific PMRs and SMRs for white women in chicken slaughtering plants $(n=484)$ : Meatcutters Union, Baltimore, Maryland (1949-80). (Figures in parentheses represent SMRs obtained for persons who had ever worked in chicken slaughtering plants)

\begin{tabular}{llcccc}
\hline Type of cancer & $\begin{array}{l}\text { ICD 8th } \\
\text { revision }\end{array}$ & $\begin{array}{l}\text { Observed } \\
\text { No of deaths }\end{array}$ & PMR & $\begin{array}{l}\text { Lost are alive } \\
\text { SMR }\end{array}$ & $\begin{array}{l}\text { Lost are withdrawn } \\
\text { SMR }\end{array}$ \\
\hline All haemopoietic/lymphatic cancers & $200-209$ & 0 & & & \\
Lung & $162-163$ & 3 & $3 \cdot 81^{*}$ & $4 \cdot 56^{*}($ NA) & NA \\
All cancers & $140-209$ & 6 & $0 \cdot 89$ & $1 \cdot 04(1 \cdot 13)$ & $1 \cdot 11$ \\
All causes of death & & 21 & $1 \cdot 18(1 \cdot 16)$ & $1 \cdot 26$ \\
\hline
\end{tabular}

*p-value $<0.05$

been members of the union for less than five years (a similar occurrence was observed in meatpacking plants).

When only residents of Baltimore were considered, the SMR for lung cancer for the period 1970-80 was 1.37 using United States rates and 0.80 using Baltimore rates (neither of which was statistically significant). Thus the excess risk in the group as a whole may be real, though probably slightly less than twofold.

\section{Breast cancer (ICD 174)}

The low SMR of 0.49 in this group which was statistically significant is probably related to the fact that it was based on the conservative assumption that all those lost to follow up were alive, as neither the corresponding PMR of 0.56 nor the other SMR of 0.52 calculated with subjects lost to follow up withdrawn at the time of loss, differed significantly from unity (table 4).

\section{CHICKEN SLAUghtering PLANTS}

No deaths from tumours of the haemopoietic/ lymphatic systems were observed in this group (0.6 expected). The only non-haemopoietic/lymphatic cancer that was significantly raised was lung cancer (table 5).

\section{Lung cancer (ICD 162-163)}

The PMR for lung cancer in this group was 3.81 (p < 0.025 ) and the SMR of 4.56 was also statistically significant. All three deaths occurred under the age of
50 and the SMRs for these ages varied between 8.0 and 52.9. (One of the three deaths was due to ICD 163.) All three had been members of the union for less than five years. None of the deaths occurred among workers who lived in Baltimore (most of the chicken plants were situated outside Baltimore).

\section{NON-MEAT COMPANIES}

No death from tumours of the haemopoietic/ lymphatic systems was observed in this control group even though three were expected and no statistically significant SMRs or PMRs were observed for any cancer (table 6). It is to be noted that the SMR for lung cancer was only $1 \cdot 11$ and all four deaths observed occurred after the age of 49 .

\section{Discussion}

The results obtained by the different estimates of risk were remarkably consistent. At least a threefold risk for myeloid leukaemia and non-Hodgkin's lymphomas was observed among workers in the meat department of grocery stores/supermarkets but not in the control group of workers in non-meat companies. It is not known, however, whether these risks are peculiar to this group of workers in the meat industry, since a similar level of risk in abattoir or meatpacking plant workers would have resulted in only about one death observed in each of these groups. In the case of chicken plants. an even higher risk would have been required to observe one death. We think, therefore, that deaths from leukaemia and lymphoma were too

Table 6 Cause specific PMRs and SMRs for white women in non-meat companies $(n=1095)$ : Meatcutters Union, Baltimore, Maryland (1949-80). (Figures in parentheses represent SMRs obtained for persons who had ever worked in abattoirs)

\begin{tabular}{|c|c|c|c|c|c|}
\hline Type of cancer & $\begin{array}{l}\text { ICD 8th } \\
\text { revision }\end{array}$ & $\begin{array}{l}\text { Observed } \\
\text { No of deaths }\end{array}$ & $P M R$ & $\begin{array}{l}\text { Lost are alive } \\
\text { SMR }\end{array}$ & $\begin{array}{l}\text { Lost are withdrawn } \\
\text { SMR }\end{array}$ \\
\hline $\begin{array}{l}\text { All haemopoietic/lymphatic cancers } \\
\text { All cancers } \\
\text { All causes of death }\end{array}$ & $\begin{array}{l}200-209 \\
140-209\end{array}$ & $\begin{array}{r}0 \\
29 \\
132\end{array}$ & 0.83 & $\begin{array}{l}0.83(0.84) \\
1.08(1.07)\end{array}$ & $\begin{array}{l}1 \cdot 04 \\
1 \cdot 37^{*}\end{array}$ \\
\hline
\end{tabular}

*p-value $<0.05$ 
few in the other job categories to examine in detail which occupational exposures were likely to explain the observed excesses. It should be noted, however, that in our examination of the data for men in grocery stores/supermarkets, despite ample data, we did not observe an excess of any tumour of the haemopoietic/lymphatic systems. ${ }^{26 a}$ Since there is hardly any difference in the handling of meat between men and women in this job category (if there is, it is probably more in men) then, barring biological differences in response to the same exposure, the absence of excess of leukaemia and non-Hodgkin's lymphoma in men would preclude all other occupational exposures as a possible cause, except exposure to fumes from the wrapping or labelling of meat. This is the only exposure for which there is pronounced difference between the sexes in this category of workers, for whereas women spend virtually all their time wrapping and labelling meat, men spend no more than $15 \%$ of their time on this activity (D Wegman, unpublished data). Thus exposure to fumes associated with this activity is the occupational exposure most likely to explain these excesses if they are real, particularly as it is known that benzene, a substance believed to cause myeloid leukaemia and non-Hodgkin's lymphoma in man ${ }^{1127-29}$ is found in the highest concentration in the hydrocarbon fraction of the thermal decomposition products emitted when polyvinyl chloride plastic film used to wrap meat is heated. ${ }^{7810}$ Since the excess of leukaemia and lymphoma observed in women in this category were based on rather few cases, however, caution should be exercised in their interpretation and chance cannot be ruled out.

A twofold risk of death from lung cancer, which was significant, was observed for all women in the union as a whole. This excess was associated mainly with workers in meatpacking plants, grocery stores, and chicken slaughtering plants. In the case of meatpacking plants and chicken plants workers at least a threefold statistically significant risk persisted after controlling for geographical variation. A characteristic feature of the deaths from lung cancer is illus- trated in table 7. In the control group of workers in $\overline{\bar{\alpha}}$ non-meat companies not only was the SMR for lung? cancer not raised but none of the lung cancer deaths $\stackrel{\varnothing}{\varnothing}$ in this group occurred before the age of 50 . On the other hand, within the meat industry, it is evident $\stackrel{\vec{P}}{\longrightarrow}$ from the table that there is a direct linear relation? between the proportion of deaths from lung cancer $\overline{0}$ under age 50 and the risk of death from the disease. $\frac{\bar{\sigma}}{\partial}$ This relation occurred even though the age distribu- $\stackrel{\varnothing}{\varnothing}$ tions of members in all the different job categories were similar. This is borne out by the fact that the SMRs obtained for the group aged under $50,$. especially in meatpacking plants and chicken plants, $\vec{\omega}$ were extremely high (between 8.0 and 52.9). It should $\stackrel{\sigma}{\omega}$ also be noted that in the Baltimore general population only $8.1 \%$ of all deaths from lung cancer 3 occurred under the age of 50 during the period $\vec{\omega}$ 1969-80 (A Gittelsohn, unpublished data). These 0 results suggest that there is a real risk of death from if lung cancer among women in the meat industry, and $V$

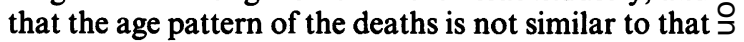
observed for deaths from lung cancer in the general $\vec{c}$ population, most of which are associated with ciga- $\mathbb{D}$ rette smoking; there seems to be a definite predilec- $\frac{\bar{T}}{\mathbb{D}}$ tion for induction of the disease at a younger age. $\frac{\mathbb{D}}{3}$ Although in this study the duration of union membership may not be an accurate surrogate for the duration of employment, it is perhaps not mereg $\emptyset_{\infty}$ coincidence that in the three job categories in whie lung cancer was significantly raised 21 of the total 8 29 deaths from lung cancer (72\%) occurred amon those who had been members of the union for less $\frac{\partial}{\partial}$ than five years, suggesting that a short period of exposure to the putative carcinogen is required to $\frac{\mathbb{Q}}{\square}$ induce the disease.

What then are the likely occupational causes of the excess of lung cancer in the industry? Air pollution is $\frac{3}{\sqrt{3}}$ believed to be contributory to the high incidence of lung cancer observed in urban areas since pollutants in city air include many of the carcinogens found in $\mathbb{D}$ tobacco. ${ }^{30}$ In meatpacking plants and abattoirs with large meatpacking departments considerable pollution of the ambient air occurs in the smoke house.

Table 7 Relation between SMRs for all lung cancer deaths and percentage of lung cancer deaths occurring before the age of 50 in white women: Meatcutters Union, Baltimore, Maryland (1949-80)

\begin{tabular}{|c|c|c|c|c|}
\hline \multirow[b]{2}{*}{ Job category } & \multirow{2}{*}{$\begin{array}{l}\text { No of } \\
\text { lung cancer deaths } \\
\text { all ages }\end{array}$} & \multicolumn{2}{|c|}{ Lung cancer deaths at age $<50$} & \multirow{2}{*}{$\begin{array}{l}\text { Lung cancer deaths } \\
\text { all ages } \\
\text { SMR }\end{array}$} \\
\hline & & No & $\%$ & \\
\hline Non-meat & 4 & 0 & 0 & $1 \cdot 11$ \\
\hline $\begin{array}{l}\text { Abattoir } \\
\text { Grocery } \\
\text { Meatpacking } \\
\text { Chicken }\end{array}$ & $\begin{array}{r}5 \\
14 \\
12 \\
3\end{array}$ & $\begin{array}{l}1 \\
5 \\
8 \\
3\end{array}$ & $\begin{array}{r}20 \\
36 \\
67 \\
100\end{array}$ & $\begin{array}{l}1.41 \\
1.95 \\
4.02 \\
4.56\end{array}$ \\
\hline
\end{tabular}


Although we do not know of any studies on the carcinogenic constituents of smoke emitted in these places, it may possibly contain carcinogens found in tobacco. This type of pollution is unlikely to give rise to the excess of lung cancer observed, however, because smoking of meat is usually a male job, with only a handful of people exposed at a time in a fairly secluded part of the plant. In one study air sampling and blood samples from workers failed to show evidence of smoke pollution in areas other than within the smoke house. ${ }^{4}$ Furthermore, smoking of meat does not occur in grocery stores/supermarkets and in chicken slaughtering plants, two categories where a significant excess risk of the disease was observed. Similarly exposure to nitrosamines, BHT, or BHA is an unlikely cause, as such exposures do not occur in chicken slaughtering plants and are probably negligible, if they occur at all, in grocery stores/supermarkets. Exposure to BLV is also an unlikely cause, as only a slight excess risk of lung cancer was observed in abattoir workers who have the highest exposure to BLV and, moreover, exposure to BLV does not occur in chicken slaughtering plants. Conversely, exposure to the avian leukosis viruses and Marek's disease virus, which is highest in chicken slaughtering plants does not occur in abattoirs or in meatpacking plants where a high risk was observed, hence these are also unlikely causes.

The only exposure in the industry that fits the observed pattern of occurrence of the excess of lung cancer is exposure to fumes emitted either during the wrapping or labelling of meat. This is the predominant activity in which women in the meat industry are engaged, and it is common to all job categories within the meat industry. It is known for certain that this exposure was intense in some of the meatpacking plants (from discussion with women who worked in these plants) and that some chicken plants and many grocery stores/supermarkets used heat to cut and seal the plastic film in which meat was wrapped or to activate the adhesive price labels. On the other hand, it was also known that most of the women in the abattoir group in this study were derived from a large company that did not use heat to cut and seal plastic films, which could explain why only a slight nonsignificant excess risk of lung cancer was observed in abattoir workers.

It is not possible from this type of study to incriminate any exposure as the definite cause of the excess of lung cancer observed in women in the meat industry; however, exposure to fumes emitted during the wrapping and labelling of meat is suggestive and should be investigated as one that may play a part either by itself or synergistically with cigarette smoking in the aetiology of this disease in the industry. The possibility also exists that some other exposure which we have not taken into account may well be responsible. This study is the first to examine the occurrence of cancer in women in this industry and should, therefore, be considered as exploratory. The findings need to be confirmed, but the excess of lung cancer we observed is consistent with reports of an excess of lung cancer in butchers and meatcutters from the analysis of national statistics over different periods in England and Wales, Denmark, and Sweden, 31-33 and also from other studies. ${ }^{3435}$ Studies incorporating a much more stringent definition of exposure on an individual basis than was possible in this study, and which will take into account the effect of confounding factors such as cigarette smoking, are necessary before a particular exposure may be incriminated.

This study was supported by grant CA $30410-3$ from the National Cancer Institute. We are indebted to Jerry Menapace, William Brown, Bruce Drasal, Pete Morris, and the rest of the staff of the Baltimore Meatcutters Union for their valuable support and help throughout the study; we also acknowledge the help provided by Ilene Bloom of the Data Analysis Department and Danielle Jones, Debbie Mason, Ruby Haire, and Sherry Shenning, research assistants at the Johns Hopkins University and the Division of Vital Records, the Motor Vehicle Administration of the State of Maryland, the Health Care Financing Administration, and the Veterans Administration.

Requests for reprints to: Dr Eric S Johnson, Division of Analytical Epidemiology, International Agency for Research on Cancer, 150 course Albert-Thomas, 69372 Lyon Cedex 08, France.

\section{References}

1 Sokol WN, Aelony Y, Beall GN. Meatwrapper's asthma. A new syndrome? JAMA 1973;226:639-41.

2 Andrasch RH, Bardana EJ. Thermoactivated price-label fume intolerance. A cause of meat-wrapper's asthma. JAMA 1976;235:937.

3 Vandervort T, Brooks SM. Polyvinyl chloride film thermal decomposition products as an occupational illness. 2. Clinical studies. J Occup Med 1977;19:192-6.

4 Johnson CJ, Anderson HW. Meat wrapper's asthma: a case study. J Occup Med 1976;18:102-4.

5 Fleet SM. Respiratory symptoms of employees of retail meat departments. Public Health Rep 1977;92:545-53.

6 International Agency for Research on Cancer. Monographs on the evaluation of carcingenic risk of chemicals to humans. Some monomers, plastic and synthetic elastomers and acrolein. Vol 19. Lyon: IARC, 1979:1-438.

7 O'Mara MM. High temperature pyrolysis of poly(vinyl chloride): gaschromatographic-mass spectrometric analysis of the pyrolysis products from PVC resin and plastisols. Journal of Polymer Science 1970;8:1887-99.

8 Takahashi T, Serizawa M. Pyrolysis of polyvinyl chloride. Plastics Industry News 1972;12:17-21. 
9 Polakoff PL, Lapp L, Reger R. Polyvinyl chloride pyrolysis products. Arch Environ Health 1975;30:269-71.

10 Vandervort R, Brooks SM. Polyvinyl chloride film thermal decomposition products as an occupational illness. I. Environmental exposures and toxicology. J Occup Med 1977;19: 188-91.

11 Adamson R, Seiber SM. Chemically-induced leukaemia in humans. Environ Health Perspect 1981;39:93-103.

12 International Agency for Research on Cancer. Monographs on the evaluation of carcinogenic risk of chemicals to humans. Some industrial chemicals and dyestuffs. Vol 29. Lyon: IARC, 1982:269-85.

13 Olson C. Bovine lymphosarcoma (leukaemia)-a synopsis. J Am Vet Med Assoc 1974;165:630-2.

14 Burmester BR, Purchase HG. Occurrence, transmission and oncogenic spectrum of the avian leukosis viruses. Bibl Haematologica 1970;36:83-95.

15 Nazerian K. Marek's disease lymphoma of chicken and its causative herpes virus. Biochim Biophys Acta 1979;560:375-95.

16 Statistical summary: federal meat and poultry inspection for calendar year 1978. Meat and poultry inspection program. Washing ton: US Department of Agriculture, Food Safety and Quality Service.

17 Burridge MG, Puhr DM, Henneman JM. Prevalence of bovine leukaemia virus infection in Florida. J Am Vet Med Assoc 1981;179:704-7.

18 Purchase HG, Burmester BR. Leukosis/sarcoma group. In: Hofstad MS, Calnek BW, Helmboldt CS, Reid WM, Yoder HW Jr, eds. Diseases of poultry. 6th ed. Ames, Iowa: Iowa State University Press, 1972:502-68.

19 Purchase HG. Marek's disease: epizootiology, control and relationship to oncornaviruses. Bibl Haematologica 1976;43: 199-203.

20 Calnek BW, Witter RL. Marek's disease. In: Hofstad MS, Calnek BW, Helmboldt CS, Reid WM, Yoder HW Jr, eds. Diseases of poultry. 6th ed. Ames, Iowa: Iowa State University Press, 1972:470-501.

21 Sen NP, Donaldson B, Charbonneau C, et al. Effect of additives on the formation of nitrosamines in meat curing mixtures con- taining spices and nitrite. J Agric Food Chem 1974;22:1125-30; 22 Sen MP, Miles WF, Donaldson B, et al. Formation of nitrosamines in meat curing mixture. Nature 1973;245:104-5.

23 International Agency for Research on Cancer. Monographs on the evaluation of carcinogenic risk of chemicals to humans. Some $N$-nitroso compounds. Vol 17. Lyon: IARC, 1978:51-75, 83-125,287-335.

24 Ito N, Fukushima S, Hagiwara A, Shibata M, Ogiso T. Carcinogenicity of butylated hydroxyanisole in F344 rats. $J$ Natl Cancer Inst 1983;70:343-52.

25 Williams GM, Maeura Y, Weisburger JH. Simultaneous inhibition of liver carcinogenicity and enhancement of bladder $\stackrel{\mathbb{Q}}{\varrho}$ carcinogenicity of $\mathrm{N}$-2-fluorenyl-acetamide by butylated hydroxytoluene. Cancer Lett 1983;19:55-60.

26 Block G, Matanoski GM, Seltser RS. A method for estimating $\vec{\circ}$ year of birth using social security number. Am $J$ Epidemiol 1983;118:377-95.

26a Johnson ES, Fischman HR, Matanoski GM, Diamond E. Cancer mortality among white males in the meat industry $J$ Occup Med 1986;28:23-32.

27 Monson RR, Nakano KK. Mortality among rubber workers. 1. White male union employees in Akron, Ohio. Am J Epidemiol 1976;13:284-96.

28 McMichael AJ, Spiritas R, Kupper LL. An epidemiologic study or of mortality within a cohort of rubber workers, 1964-72. V J Occup Med 1974;16:458-63.

29 Vianna NJ, Polan A. Lymphomas and occupational benzene $\stackrel{ }{ }$ exposure. Lancet 1979; i:1394-5.

30 Israel L, Chahinian AP. Lung cancer: national history, prognosis $\odot$ and therapy. New York: Academic Press, 1976.

31 Fox AJ, Lynge E, Malker $\mathrm{H}$. Lung cancer in butchers. Lancet 1982;i:165-6.

32 Griffith W. Lung cancer in butchers. Lancet 1982;i:399.

33 Lynge E, Andersen O, Kristensen TS. Lung cancer in Danish butchers. Lancet $1983 ;$; $527-8$.

34 Doerken H, Rehpenning W. Lung cancer in butchers. Lan@et 1982;i:561.

35 Johnson ES, Fischman HR. Cancer mortality among butche and slaughterhouse workers. Lancet 1982;i:913-4. 